http://jmscr.igmpublication.org/home/ ISSN (e)-2347-176x ISSN (p) 2455-0450 crossref DOI: https://dx.doi.org/10.18535/jmscr/v8i8.52

\author{
Journal Of Medical Science And Clinical Research

\title{
Giant Epidermoid Cyst: An Uncommon presentation of a Common Entity
}

\author{
Authors \\ Rohit Kumar $^{1}$, Ritu Rawat ${ }^{2}$, Vandna Raghuvanshi ${ }^{3}$, Arvind Bhatia ${ }^{1 *}$, \\ Dilbag Singh ${ }^{4}$, Ankit Sharma ${ }^{5}$ \\ ${ }^{1}$ M.O. Specialist, General Surgery, Pt. JLNGMC, Chamba, H.P., India \\ ${ }^{2}$ Assistant Professor, Dermatology, Pt. JLNGMC, Chamba, H.P., India \\ ${ }^{3}$ Assistant Professor, Radiodiagnosis, Pt. JLNGMC, Chamba, H.P., India \\ ${ }^{4}$ Senior Resident, Dermatology, Pt. JLNGMC, Chamba, H.P., India \\ ${ }^{5}$ M.O. Specialist, General Surgery, Zonal Hospital, Solan, H.P., India \\ *Corresponding Author \\ Arvind Bhatia \\ Department of General Surgery, Pt. JLNGMC Chamba (H.P.), Pin code 176310, India
}

\begin{abstract}
Epidermoid cysts are the developmental cysts affecting people of any age and gender. Usually, the cysts are asymptomatic and require no treatment. But secondarily infected cysts cause intense pain and discomfort and warrant complete excision. Giant cysts can rarely lead to malignancies. Histopathology can help to confirm the diagnosis and rule out the malignant transformation.
\end{abstract}

Keywords: Epidermoid cyst, Giant cyst, Sebaceous Cyst, Developmental cyst, keratin cyst.

\section{Introduction}

Epidermoid cyst is a developmental cyst mainly originating in the head and neck region ${ }^{[1]}$ Also known as epidermal cyst, epidermal inclusion cyst, sebaceous cyst, epithelial cyst, keratin cyst $^{[2]}$. On histology, the cysts are lined by stratified epithelium and filled with a keratinous material. An epidermal punctum is a hallmark for making the clinical diagnosis. People of any age and gender can be involved, though young males are affected most commonly $^{[3]}$. Generally, the cysts are asymptomatic and require no treatment, but secondarily infected cysts need complete excision of the cyst wall and its contents to prevent recurrence and scarring. Giant epidermoid cysts more than $5 \mathrm{~cm}$ in diameter can cause problems, particularly in the head-and-neck region $^{[4,5]}$. Malignant transformation of an epidermoid cyst can be a rare possible event. Squamous cell carcinoma, basal cell carcinoma, and Merkel cell carcinoma have been reported to arise in the epidermoid cysts ${ }^{[6,7,8]}$. We report a case of giant epidermoid cyst treated successfully with surgery.

\section{Case Report}

45 years old male presented to the Surgery OPD with a painful swelling over the left shoulder. Swelling was present for the last 20 years, was asymptomatic and slowly progressive. Developed throbbing pain and redness 10 days back. General and systemic examination revealed no abnormality. On local examination, there was single erythematous globular swelling of size around $14 *$ $10 \mathrm{~cm}$ over left shoulder region (Figure 1). 


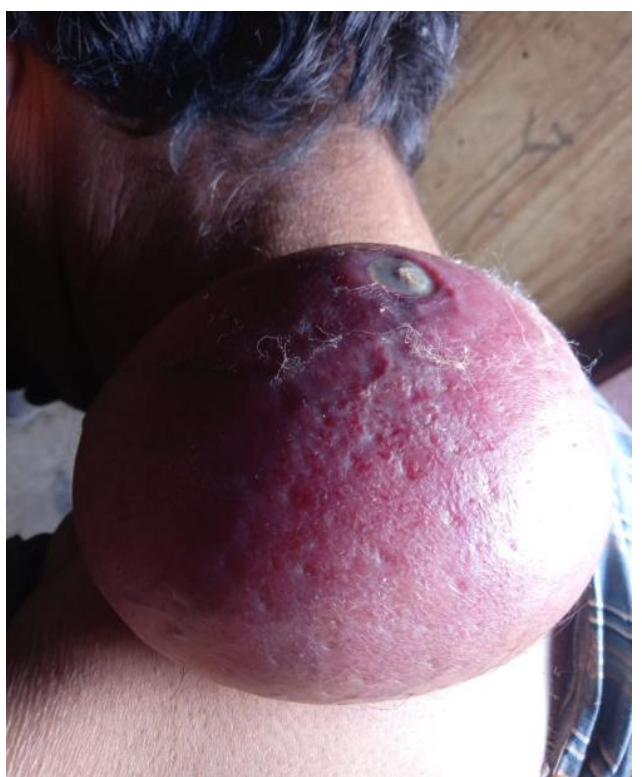

Figure 1: Swelling with central punctum

It was soft in consistency, fluctuant with smooth surface, well defined margins, fixed to the skin but not to the underlying structures, tender with discharging sinus over the skin with whitish cheesy material coming through sinus (Figure 2).

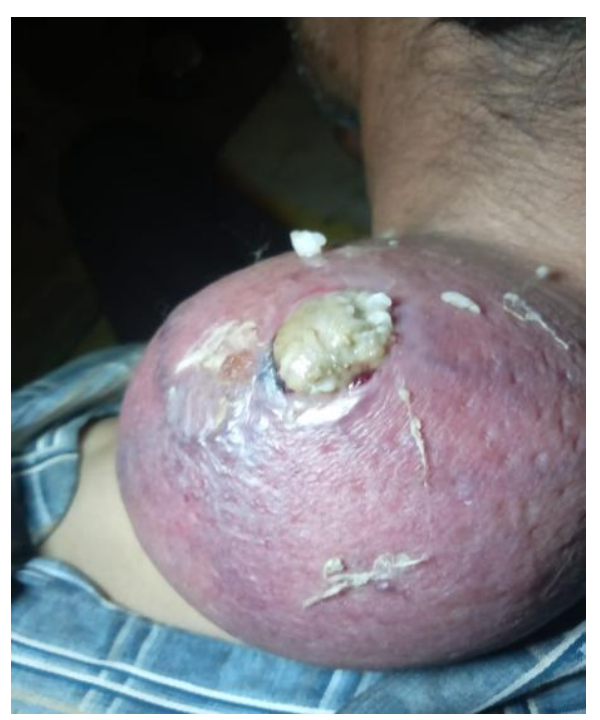

Figure 2: Cheesy material coming through punctum

There was no regional lymphadenopathy or bruit or pulsations. A preliminary diagnosis of giant epidermoid cyst was proposed. Since the swelling was more than $5 \mathrm{~cm}$, possibility of malignancy was also considered. Ultrasonography of swelling showed heterogenously hypoechoic lesion with hyperechoic areas in it and increased vascularity measuring $11.4 * 9.8 * 10 \mathrm{~cm}$. No mobile echos were seen. Possibility of mesenchymal tumour was kept. Fine needle aspiration cytology showed features of keratinous cyst. Excision of the cyst under local anaesthesia was done and sent for histopathology (Figure 3). Grossly, it was cystic mass of size $15^{*} 10 \mathrm{~cm}$ in size, globular, greyish white in colour (Figure 4). Histopathology was suggestive of epidermoid cyst with no malignant changes. Post operative course was favourable.

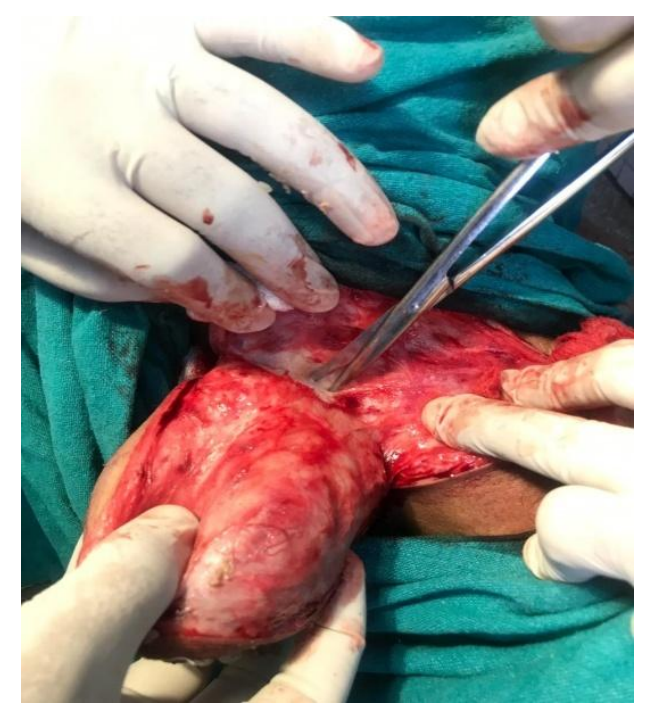

Figure 3: Epidermoid cyst during excision

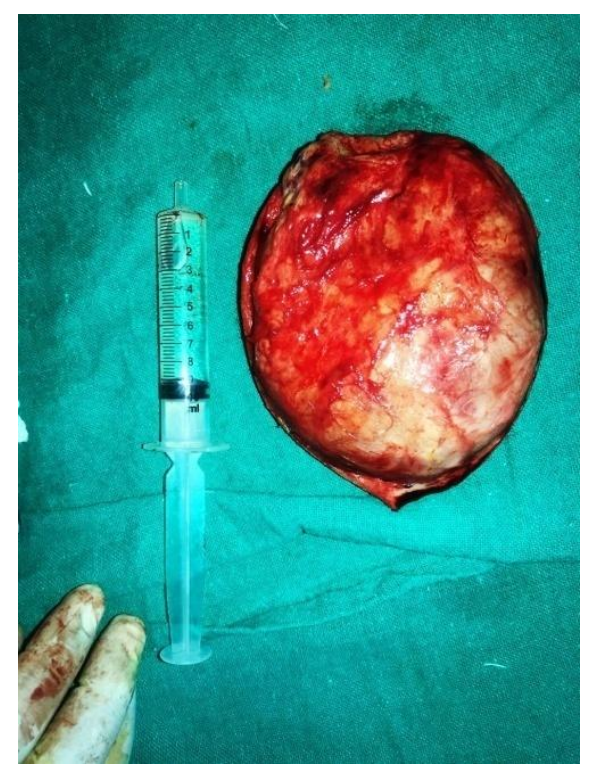

Figure 4: Epidermoid cyst after excision

\section{Discussion}

Epidermoid cysts are benign, slow growing, congenital or acquired, subcutaneous lesions presenting as nodules or tumours ${ }^{[9]}$. Epidermoid cysts are formed either by the sequestration and implantation of epidermal rest during the embryonal 
period or by the occlusion of the pilosebaceous unit or the iatrogenic implantation of epithelium or due to the proliferation of epidermal cells within the dermis. Inflammation is in part mediated by the keratinous material contained in epidermoid cysts.

Various causes like infection with Human Papilloma Virus ${ }^{[10]}$, crush injuries ${ }^{[11]}$, cases after skin transplantation ${ }^{[12]}$, cryotherapy for wart $^{[13]}$, repeated physical loading ${ }^{[14]}$ on the area have been implicated as the additional etiological factors.

Although seen commonly on the hair bearing areas with head and neck accounting for around 7\% cases $^{[15]}$, they have been seen on the mucosae and glabrous skin.

Various differential diagnosis include lipoma, dermoid cyst, trichelemmal cyst, pilomatricoma.

Large size of the cyst in our case led to the possibility of malignant transformation, though rare, with the differential diagnosis of squamous cell carcinoma, basal cell carcinoma, Bowens disease. Histopathological examination, excluded malignancy in our patient.

In present case, surgical removal followed by histopathology confirmed the diagnosis, ruled out malignancy and its success was confirmed by no recurrence of the lesion. Thus, the giant lesions warrant the use of histopathology to rule out malignancy.

\section{Acknowledgement: Nil}

\section{References}

1. Shear M. Developmental cyst of head and neck region. Cyst of oral and maxillofacial region Shear. 4th ed. Oxford: Blackwell Publication; 2007. p. 181-3.

2. Rajendran R. Developmental disturbances of oral and para oral Structures. Shafer's textbook of oral pathology. 6th ed. Elsevier publication a division of Reed Elsevier India private limited Noida(UP); 2009 p. 67-9.

3. Plewig G, Landthaler M, Burgdorf W, Hertl M, Ruzicka T (eds.). Braun-Falco's Dermatologie, Venerologie und Allergologie. 6th edition. Berlin - Heidelberg: Springer,
2012. https://doi.org/10.1007/978-3-64224163-5

4. Utumi ER, Araujo JP, Pedron IG, Yonezaki F, Machado GG, Rocha AC. Extensive epidermoid cyst of the submental region. Autops Case Rep. 2016; 6(2):51-4. https://doi.org/10.4322/acr.2016.031 PMid:27547744 PMCid:PMC4982785 .

5. Nishar CC, Ambulgekar VK, Gujrathi AB, Chavan PT. Unusually giant sublingual epidermoid cyst: a case report. Iran J Otorhinolaryngol. 2016; 28(87):291-6. PMid:27602342 PMCid:PMC4994990

6. Liau JL, Altamura D, Ratynska M, Verdolini R. Basal cell carcinoma arising from an epidermal cyst: when a cyst is not a cyst. Case Rep Dermatol. 2015; 7(1):75-8. https://doi.org/10.1159/000381393 PMid:26034477 PMCid:PMC4448066

7. Sze S, Richmond I, Bickers A, Saha A. Squamous cell carcinoma arising from a vulval epidermal cyst. J Obstet Gynaecol Res. 2016; 42(11):1623-6. https://doi.org/10.1111/jog.13091 PMid:27785896

8. Aljufairi E, Alhilli F. Merkel cell carcinoma arising in an epidermal cyst. Am J Dermatopathol. 2016; [Epub ahead of print

9. Wollina U, Langner D, Tchernev G, França K, Lotti T. Epidermoid Cysts - A Wide Spectrum of Clinical Presentation and Successful Treatment by Surgery: A Retrospective 10-Year Analysis and Literature Review. Open Access Maced J Med Sci. 2018 Jan 25; 6(1):28-30. https://doi.org/10.3889/oamjms.2018.027

10. Dive AM, Khandekar S, Moharil R, Deshmukh S. Epidermoid cyst of the outer ear: A case report and review of literature. Indian J Otol 2012;18:34-7.

11. Ikegami T, Kameyama M, Orikasa $H$, Yamazaki K. Trichilemmal cyst in the pulp of the index finger: a case report. Hand Surgery $2003 ; 8: 253-5$. 
12. Henry FP, Healy CE, O'Broin E. Epidermoid cyst post dermofasciectomy. Journal of Plastic, Reconstructive Aesthetic Surgery 2010;63:e44-5.

13. Haga T, Okuyama R, Tagami H, Egawa K, Aiba S. Demonstration of human papillomavirus type 60 in an epidermoid cyst developing in the finger pulp of the thumb. Dermatology 2005;211:296-7.

14. De Giorgi V, Sestini S, Nardini P, Lotti T. Palmoplantar cysts: sebaceous or epidermoid cysts. Journal of the European Academy of Dermatology and Venereology 2006;20: 1026-7.

15. Janarthanam J, Mahadevan S. Epidermoid cyst of submandibular region. J Oral Maxillofac Pathol. 2012; 16(3):435-7. https://doi.org/10.4103/0973-029X.102511 PMid:23248482 PMCid:PMC3519225. 